\title{
Combination immunotherapy with oncolytic vaccinia virus and checkpoint inhibitor following local tumor irradiation
}

Boris Minev ${ }^{1,2^{*}}$, Holbrook Kohrt ${ }^{3}$, Mehmet Kilinc ${ }^{2}$, Nanhai Chen², Audrey Feng ${ }^{2}$, Maysam Pessian², Ulrike Geissinger ${ }^{2}$, Erik Haefner ${ }^{4}$, Desislava Tsoneva ${ }^{4}$, Kliment Bozhilov ${ }^{5}$, Idit Sagiv-Barfi ${ }^{3}$, Xing Zhao ${ }^{3}$, Narendiran Rajesekaran ${ }^{3}$, Ronald Levy ${ }^{3}$, Aladar Szalay ${ }^{2}$

From Society for Immunotherapy of Cancer 29th Annual Meeting National Harbor, MD, USA. 6-9 November 2014

Oncolytic virotherapy is safe and clinically active in solid tumors, however its efficacy in hematologic malignancies as well as in combination with checkpoint inhibitors and radiation is unexplored. To simulate advanced lymphoma,
A20 cells were injected subcutaneously on bilateral flanks of BALB/c mice and treatment initiated on day 17 to only the right flank tumor with local irradiation (Irr), intratumoral (i.t.) vaccinia virus (VACV) and i.t. anti-CTLA-4

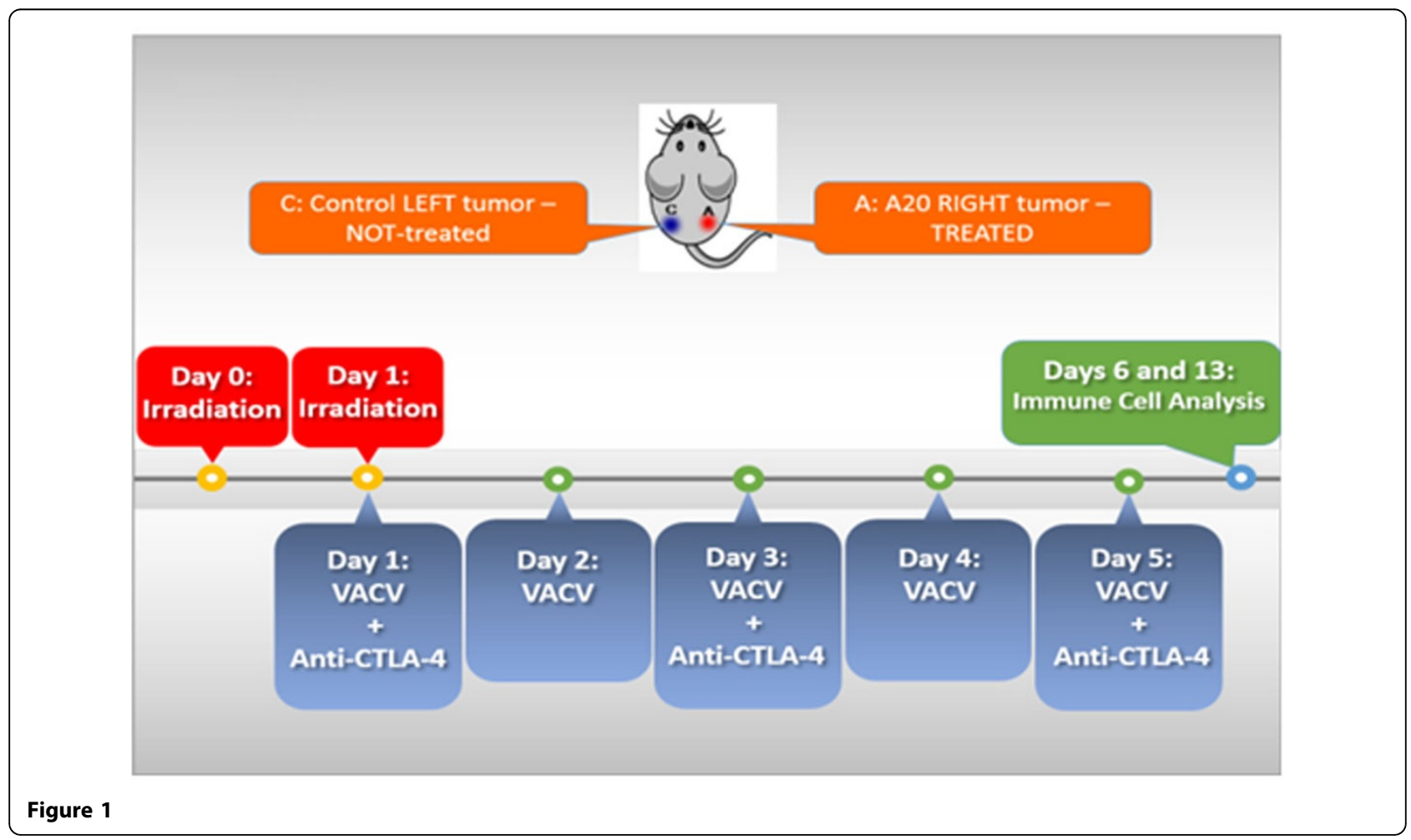

'University of California San Diego, San Diego, CA, USA

Full list of author information is available at the end of the article

(c) 2014 Kohrt et al.; licensee BioMed Central Ltd. This is an Open Access article distributed under the terms of the Creative Commons 
mAb (Irr-VACV-CTLA4, Figure 1). The Irr-VACVCTLA4 regimen was the most effective in eradicating or shrinking both treated and untreated tumors and extending survival, followed by the Irr-VACV regimen. Treatment with Irr-VACV-CTLA4, led to initially a mature, activated NK cell $\left(\mathrm{KLRG}^{+} \mathrm{CD} 27^{+}\right)$infiltrate (day 6 posttreatment) followed by a $\mathrm{CD}^{+} \mathrm{T}$ cells infiltrate $($ day +13$)$ in treated tumors. In contrast, treatment with VACVCTLA4 led to activated NK cell accumulation $($ day +6$)$ followed by a $\mathrm{CD}^{+} \mathrm{T}$ cell infiltrate $(\mathrm{day}+13)$ in non-treated tumors. Importantly, $\mathrm{CD} 8^{+} \mathrm{CD} 44^{\mathrm{hi}} \mathrm{T}$ cells isolated from the blood and spleens of the treated mice showed functional specificity to A20 lymphoma cells, but not to MHCmatched tumor cells (CT26) in intra-cellular stains for IFN- $\gamma$. Splenocyte-derived A20-specific CD $8^{+} C D 44^{\text {hi }}$ $\mathrm{T}$ cells were induced most efficiently in the Irr-VACVCTLA4 regimen-treated mice, while blood-derived A20specific $\mathrm{CD} 8{ }^{+} \mathrm{CD} 44^{\text {hi }} \mathrm{T}$ cells were induced most efficiently in the Irr-VACV regimen-treated mice. Viral plaque assays (VPA) showed lack of live viral particles in both treated and untreated tumors upon sacrificing mice 4 to 10 weeks after treatment initiation. Surprisingly, VPA assays identified live virus in the livers of Irr-VACV-CTLA4 regimentreated mice, which paralleled a reduced metastatic load.

Our findings are the first to demonstrate the potential of combination immunotherapy with oncolytic viruses and checkpoint inhibitors in hematologic malignancies. The antitumor activity is attributed to the induction of an effective and specific immune response. This finding is corroborated by the significant infiltration with mature activated NK cells, followed by $\mathrm{CD}^{+} \mathrm{T}$ cells, in both treated and untreated tumors. Importantly, the tumor-specific $\mathrm{CD}^{+} \mathrm{T}$ cells showing a memory phenotype $\left(\mathrm{CD} 44^{\mathrm{hi}}\right)$ suggest the effective induction of a potent immune memory response. Effective targeting of distant metastases after intratumoral administration is also an important finding with significant clinical implications. This novel combination immunotherapy with oncolytic viruses and checkpoint inhibitors following local tumor irradiation is now being translated to a Phase I proof-of-concept clinical trial in non-Hodgkin's lymphoma at our institution.

\section{Authors' details}

${ }^{1}$ University of California San Diego, San Diego, CA, USA. ${ }^{2}$ Genelux

Corporation, San Diego, CA, USA. ${ }^{3}$ Stanford University, Stanford, CA, USA.

${ }^{4}$ University of Wurzburg, Germany. ${ }^{5}$ University of Hawaii, HI, USA.

Published: 6 November 2014

doi:10.1186/2051-1426-2-S3-P112

Cite this article as: Minev et al:: Combination immunotherapy with oncolytic vaccinia virus and checkpoint inhibitor following local tumor irradiation. Journal for ImmunoTherapy of Cancer 2014 2(Suppl 3):P112.

\section{Submit your next manuscript to BioMed Central} and take full advantage of:

- Convenient online submission

- Thorough peer review

- No space constraints or color figure charges

- Immediate publication on acceptance

- Inclusion in PubMed, CAS, Scopus and Google Scholar

- Research which is freely available for redistribution 